International Business and Global Economy 2019, no. 38, pp. 78-104

Biznes międzynarodowy w gospodarce globalnej 2019, nr 38, s. 78-104

Edited by the Institute of International Business, University of Gdańsk

ISSN 2300-6102

e-ISSN 2353-9496

DOI 10.4467/23539496IB.19.005.11504

Jacek Pera

Uniwersytet Ekonomiczny w Krakowie

\title{
Safety of investing in Polish cooperative bonds - risk aspect
}

This paper analyses the safety of investing in Polish cooperative banks' bonds in the aspect of risk. The main purpose of the paper is to identify and analyse the risk resulting from Polish cooperative banks' issuing bonds. The paper assumes the following research hypothesis: investments in cooperative bonds are relatively safe. As a rule, cooperative banks issue bonds in pursuing their business defined in the articles of association (development of lending activity), investing in branch network or innovative technological solutions, restructuring/diversifying financing sources, restructuring maturity structure for liabilities, restructuring liability revaluation dates, or increasing regulatory capital. The analysis covered all Polish cooperative bonds issued in 2018 and maturing in 2026 , i.e. all 24 bond issues performed by 20 cooperative banks. The research identified general risks applicable to all cooperative bonds, as well as risks specific to each of the 24 bond issues analysed. Based on the classification, the cooperative bonds were divided by type into eight groups. The author adopted the method of critical analysis of literature. The modified Fisher-Weil model, risk classification on the Stanisz scale, and selected risk indicators were also used in the evaluation of the bonds. For his analysis, the author drew data from full-year, half-year, and current reports found on the Catalyst and NBP websites. The security of cooperative bonds was analysed for $\mathrm{D}$ (average duration), $\mathrm{V}$ (convexity), and the risk indicator ID (issuer's debt). The analysis revealed that investments in the bonds analysed are relatively secure. The accepted research hypothesis was therefore verified positively against these parameters. A high level of risk has been identified for the PID (profitability against the issuer's debt) indicator. Here, the research hypothesis was verified negatively.

Keywords: bonds, risk, securities, cooperative bank, security

JEL classification: G21, G31, G32

\section{Bezpieczeństwo inwestycji w obligacje spółdzielcze - aspekt ryzyka}

W artykule przeanalizowano bezpieczeństwo inwestowania $\mathrm{w}$ obligacje polskich banków spółdzielczych w aspekcie ryzyka. Głównym celem artykułu jest identyfikacja i analiza ryzyka wynikającego z emisji obligacji polskich banków spółdzielczych. W artykule przyjęto następującą hipotezę badawczą: inwestycje w obligacje spółdzielcze są stosunkowo bezpieczne. Co do zasady, banki spółdzielcze emitują obligacje $\mathrm{w}$ ramach prowadzenia działalności określonej $\mathrm{w}$ statucie (rozwój działalności kredytowej), inwestowania w sieć oddziałów lub innowacyjne rozwiązania technologiczne, restrukturyzacji/dywersyfikacji źródeł finansowania, restrukturyzacji struktury zapadalności zobowiązań, restrukturyzacji terminów przeszacowania zobowiązań lub zwiększenia kapitału regulacyjnego. Analiza objęła wszystkie polskie obligacje spółdzielcze wyemitowane 
w 2018 r. i zapadające w 2026 r., tj. wszystkie 24 emisje obligacji przeprowadzone przez 20 banków spółdzielczych. W ramach badania zidentyfikowano ogólne ryzyka mające zastosowanie do wszystkich obligacji spółdzielczych, a także ryzyka specyficzne dla każdej z 24 analizowanych emisji obligacji. W oparciu o klasyfikację obligacje spółdzielcze zostały podzielone według rodzaju na osiem grup. Autor przyjął metodę krytycznej analizy literatury. W ocenie obligacji wykorzystano również zmodyfikowany model Fishera-Weila, klasyfikację ryzyka w skali Stanisza oraz wybrane wskaźniki ryzyka. Do analizy wykorzystano dane z raportów całorocznych, półrocznych i bieżących zamieszczonych na stronach internetowych Catalyst i NBP. Bezpieczeństwo obligacji spółdzielczych analizowano dla D (średni czas trwania), V (wypukłość) oraz wskaźnika ryzyka ID (dług emitenta). Analiza wykazała, że inwestycje w analizowane obligacje są stosunkowo bezpieczne. Przyjęta hipoteza badawcza została zatem pozytywnie zweryfikowana w odniesieniu do tych parametrów. Wysoki poziom ryzyka został zidentyfikowany dla wskaźnika PID (rentowność w stosunku do zadłużenia emitenta). Tutaj hipoteza badawcza została zweryfikowana negatywnie.

Słowa kluczowe: obligacje, ryzyko, papiery wartościowe, bank spółdzielczy, bezpieczeństwo Klasyfikacja JEL: G21, G31, G32

\section{Introduction}

The main purpose of this paper is the identification and analysis of the risk resulting from Polish cooperative banks' issuing bonds. The paper assumes the following research hypothesis: investments in cooperative bonds are relatively safe. Access to financial resources significantly determines the activity of cooperative banks, especially the possibility of performing infrastructural investments or expanding lending activity translating into increased profit. As opposed to commercial banks, especially those owned by foreign or WSE-listed investors, it is difficult for cooperative banks to access assets which would be entrusted to them both in the form of deposits and own funds. These entities are usually unable to collect capital of strategic importance in a single transaction, as commercial banks do through issuing shares. Banking cooperatives in Poland can obtain financial resources from the capital market, i.e. with long repayment period, only by issuing bonds. Issuance of bonds by the cooperative banking sector is directly regulated by the Act on Bonds, and indirectly by the Banking Law and the Act on the Operations of Cooperative Banks, their Affiliation, and Affiliating Banks (henceforth the Act on Cooperative Banks).

As a rule, cooperative banks issue bonds in pursuing their business defined in the articles of association (development of lending activity), investing in branch network or innovative technological solutions, restructuring/diversifying financing sources, restructuring maturity structure for liabilities, restructuring liability revaluation dates, or increasing regulatory capital.

Systematic analysis of the matter is important due to two basic periods of bond issuance. The turning point is the year 2015. Until then, cooperative banks had 
had the right to issue debt instruments in the form of bonds under Art. 127(3)(2)(b) of the Banking Law of 29 August 1997, which classified liabilities under bonds as the bank's additional capital. The amendment to the Act on Cooperative Banks effective since 2015 prevents cooperative banks from including additional capital in the founding capital, which fundamentally changed the way banks' own funds are perceived and materially affected their solvency ratios.

While issues of debt securities do not affect basic funds, the banks will definitely still issue bonds, disclosing proceeds from the issue under supplementary funds as subordinated liabilities. Nevertheless, the risk arising from the issuing of bonds by a cooperative bank remains unchanged and resolves itself into the dangers related to: issuer bankruptcy, changes in bond market price, small bank characteristics, interrupting lending activity, ineffective market valuation of selected series of bonds, changes in interest rates, lack of liquidity, destabilisation of cooperative banking system, decrease in a bank's creditworthiness (risk of bankruptcy), lack of appropriate bond security, long redemption period, loss of proceeds from the sale of cooperative bonds, macroeconomic factors, interest rate risk, bonds duration, debt of the issuer, and profitability against debt of the issuer.

The paper is organised as follows. First, the current situation of the Polish financial sector is shortly described from the risk perspective. Then, the Polish cooperative banking system is discussed. In the next part, the risk connected with bonds issued by Polish cooperative banks is reviewed and analysed. The analysis has led to the identification of 16 main risks that are directly related to cooperative bond issues; these risks and effects of their occurrence have been analysed.

The author has adopted the method of critical analysis of literature. The modified Fisher-Weil model and selected risk indicators were also used in the evaluation of the bonds. For his analysis, the author drew data from full-year, half-year, and current reports found on the Catalyst and NBP websites.

\section{Current situation of the Polish financial sector - risk perspective}

The Polish financial system is stable, although the threats to financial stability have intensified. The stability of the financial system may be challenged by such phenomena in the external environment of the Polish economy that would result in a significant increase in uncertainty related to future developments, as well as internal phenomena and actions that might reduce the resistance of the financial system, banks in particular, to shocks.

The Polish financial system, including banks, is subject to risk factors that result not only from the country's macroeconomic situation, but also, and principally, from the Eurozone economic conditions. As a result of the most recent 
financial crisis, the situation of European banks has deteriorated to such an extent that some of them required public aid. While it helped to stabilise banking systems, it contributed to the increase in public finance deficit in some countries. The increases in deficit and public debt as well as slow pace of implementing fiscal and structural reforms have raised the Treasury bond yield, which adversely affects the financial situation of banks as main investors in bonds.

Unfavourable changes in the European financial market can have, and do have, one more negative effect. Difficult situation of foreign shareholders of banks operating in Poland forces them to sell their shares, often under pressure from their national regulators, which in this way forces banks to increase their capital and thus improve their financial stability. Such a situation is not favourable for the Polish banking sector, as it reduces trust in banks that change owners.

Despite such an unpredictable macroeconomic situation in Europe, investors see the condition of Polish economy as good, as evidenced by the prices of Polish Treasury bonds. At the end of 2018, on the background of unstable macroeconomic situation, the experts of the National Bank of Poland (NBP) assessed the Polish banking system as stable with an upward trend compared with the previous test period.

Table 1. Risks for the stability of the national financial system in 2015-2018

\begin{tabular}{|l|l|l|}
\hline \multicolumn{1}{|c|}{ Risk } & \multicolumn{1}{|c|}{ 2015-2016 } & \multicolumn{1}{c|}{$2017-2018$} \\
\hline Banking sector current situation & improvement & improvement \\
\hline Banking sector's ability to absorb shocks & improvement & no change \\
\hline $\begin{array}{l}\text { Current financial situation of non-banking financial } \\
\text { institutions }\end{array}$ & deterioration & improvement \\
\hline $\begin{array}{l}\text { Development prospects in the environment of the } \\
\text { Polish economy }\end{array}$ & deterioration & deterioration \\
\hline $\begin{array}{l}\text { Synthetic assessment of stability prospects of the } \\
\text { national financial system }\end{array}$ & no change & no change \\
\hline $\begin{array}{l}\text { The risk of another economic slowdown, which - } \\
\text { together with increased aversion to risk - can be } \\
\text { accompanied by capital outflow from Poland }\end{array}$ & increased risk & increased risk \\
\hline $\begin{array}{l}\text { The risk of reduced confidence in banks as the } \\
\text { result of owner changes }\end{array}$ & increased risk & increased risk \\
\hline $\begin{array}{l}\text { Mid-term risk: the return of excessive lending } \\
\text { activity in Poland, especially in the area of mort- } \\
\text { gage loans }\end{array}$ & increased risk & increased risk \\
\hline
\end{tabular}

Source: Own elaboration based on: [NBP, 2015; 2016; 2017; 2018].

The risk of economic slowdown, together with fiscal problems of certain EU Member States, sustains tensions in global financial markets. Poland, too, saw deteriorated prospects for the environment of the Polish economy. On the back of it, 
the risk of foreign capital outflow has risen and the trust in banks has decreased due to the risk of change of owners. Accordingly, the prospects for the Polish financial system have deteriorated. Despite unfavourable economic and market trends, the banks' financial situation improved in 2016. Nor has the banks' capital power manifested as their ability to absorb shocks deteriorated.

According to NBP analyses [NBP, 2018], the main source of market risk to which domestic banks are exposed is a mismatch between balance-sheet structure in terms of currency and interest rates. A large portfolio of foreign currency mortgage loans is a soft spot of some commercial banks. Due to borrowers' income buffers, the portfolio's quality is good despite big exchange rate shocks. Combined with banks' material capital buffers, it indicates that the economic risk related to this portfolio is not of a systemic nature. This portfolio can, however, generate systemic risk in the context of some regulatory solutions. Banks are exposed to market risk to a limited extent. Open net foreign currency position is low due to closing, by off-balance-sheet transactions, the banks' open balance-sheet currency position resulting from a large portfolio of foreign currency mortgage loans.

The risk of interest rate in the banking book is limited across the sector, although cooperative banks show a greater sensitivity of profit or loss to a possible decrease of interest rates than commercial banks do. The majority of banks, both commercial and cooperative, have a positive interest rate gap (see Figure 1). It means that interest on assets reacts to interest rate changes sharper and faster than interest on liabilities. Consequently, ceteris paribus, lowering interest rates causes decrease, and raising them causes increase in banks' net interest income/expenses. Cooperative banks are more susceptible to interest rate changes, which results from the structure of their balance-sheet interest itself, as well as from a greater share of net interest income/expenses in the profit/loss on banking operations.

A high and growing share of deposits, especially from households, and simultaneous decreasing wholesale funding favours the stability of financing of banks and mitigation of liquidity risk. The level of liquid assets is high and growing. Banks meet the regulatory liquidity indicators. Bank profitability, after excluding one-off items, decreased. In Poland, retained earnings are the basic source of capital and capital buffer level is the key parameter determining the banking sector's resistance to shocks and precondition for an increase in financing the economy.

That is why a continued downward trend would be adverse to bank profitability. Apart from the newly introduced tax on assets, main factors shaping bank profitability included increased net interest margin, decreased non-interest margin, and reduced personnel costs. The effect of credit risk cost on bank performance did not change materially.

In the Polish banking system, sound level of capital is accompanied by a low financial leverage. The average aggregate capital adequacy ratio has increased 
again and reached $17.2 \%$. The majority of banks meet regulatory requirements, including the requirement to maintain capital buffers. All banks subject to additional requirements related to the portfolio of foreign currency loans meet these requirements.

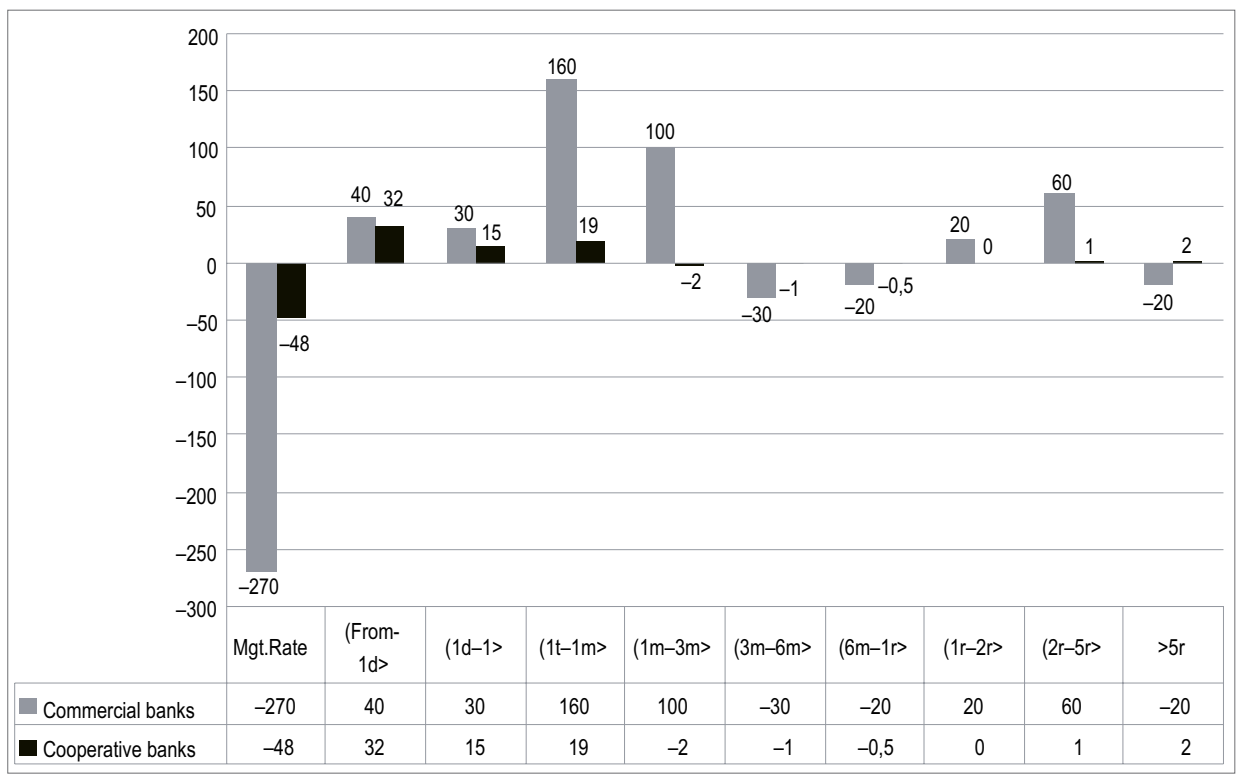

Figure 1. Interest rate gap in the banking portfolio at commercial and cooperative banks in 2018 , in \%

Note: A gap means the difference between PLN-denominated interest-bearing assets and liabilities in the given period until revaluation; $\mathrm{d}$ - working day, $\mathrm{t}$ - working week, $\mathrm{m}$ - month, $\mathrm{r}$-year; balance as of the end of December 2018 .

Source: Own elaboration based on: [NBP, 2018].

The sector of cooperative banks is stable. Most cooperative banks meet the regulatory capital and liquidity requirements. The measure that has increased the sector's robustness is what is known as an institutional protection system (IPS). Nevertheless, the environment of low interest rates and low effectiveness related to the sector's business model pose a challenge to the profitability of cooperative banks and their ability to develop. Some banks, especially larger ones, have increased their exposure to riskier assets, which, when combined with incompetent risk management, can pose a threat to their stability. Poor quality and relatively high concentration of credit portfolio with low level of coverage of impaired loans raise concerns of the sector's development. It is an adverse circumstance that a number of cooperative banks are not covered by IPS. 
To sum up: the key risks of banking sector can be classified in the following groups:

1. risk resulting from excessive increase or level of debt or financial leverage,

2. risk resulting from excessive mismatch between assets and liabilities or the risk of insufficient market liquidity,

3. risk resulting from excessive concentration of exposures to risk entities or factors and the related connections between financial system participants,

4. risk resulting from inadequate incentives driving the behaviour of financial institutions or their clients,

5. risk related to the portfolio of foreign currency loans,

6. risk related to macroeconomic situation.

The NBP calls for actions that will contribute to further strengthening of the banking system stability:

1. banks' dividend policy should allow them to hold capital necessary to maintain solvency ratio on the basis of common equity capital at the level of $9 \%$,

2. banks should increase the share of non-current liabilities in financing,

3. foreign currency mortgage loans should be a niche product, only for borrowers earning income in the loan's currency.

At the end of 2018, there were 621 banks in Poland, including 36 commercial banks, 27 branches of credit institutions, and 558 cooperative banks. The whole banking sector's aggregate equity totals above PLN 183 bn, while assets under management exceed PLN 1.7 tn [GUS, 2018] (note: GUS is the Central Statistical Office of Poland). Table 2 presents key data on the sector.

Table 2. Financial highlights of the Polish banking sector in 2017-2018, in PLN bn and \%

\begin{tabular}{|l|r|r|}
\hline \multicolumn{1}{|c|}{ Item } & 31 Dec 2017 & 31 Dec 2018 \\
\hline Balance-sheet total & $1,594,968$ & $1,706,418$ \\
\hline Capital & 175,180 & 183,789 \\
\hline Loans & $1,051,893$ & $1,105,640$ \\
\hline Deposits & 981,802 & $1,084,686$ \\
\hline Profit/loss on banking operations & 55,700 & 59,175 \\
\hline ROA & 0.81 & 0.84 \\
\hline RORC & 9.1 & 9.0 \\
\hline
\end{tabular}

Source: Own elaboration based on: [NBP, 2017; GUS, 2018].

\section{Sector of cooperative banking in Poland}

The history of cooperative banking in Western Europe dates back to the middle of the $19^{\text {th }}$ century. The profile of cooperative banking was determined by 
Franz Hermann Schultze (born in Delitzsch, Germany) and Friedrich Wilhelm Raiffeisen, who are considered precursors of the European cooperative movement [Guinnane, 1997, pp. 251-274]. As laws and regulations as well as national traditions and government structure changed from country to country, so did cooperative banking models. Despite the both organisational an operational differences, cooperative banks commenced their operations from supporting farmers and agriculture wherever such banks emerged, and their business activity has always been conducted in the interest of their members.

Currently, cooperative banks are a permanent segment of the financial market (not only in individual countries, but also internationally) and represent an important element of the European banking system [Alinska, 2002, p. 11]. Some European cooperative banking groups have a two-tier structure (e.g. in the Netherlands, Denmark, or Spain) or a three-tier structure (e.g. in Austria, Italy, or France) [Fonteyne, 2007, p. 68]. The fact is that in European countries the cooperative banking sector is among the most developed sectors of the banking industry [Desrochers, Fischer, 2005, pp. 307-354] and it enjoys EU citizens' trust greater the sector of commercial banks [Zalewska, 2009, pp. 15-17]. The confirmation of cooperative banking's significant position in Europe is its average $20 \%$ share in the market of banking services [Wyman, 2008]. Countries with the most significant cooperative banking sectors include France, Germany, Austria, and the Netherlands.

In Poland, cooperative banking has a long, over 150-year tradition and arose from the need to support local farmers, merchants, and craftsmen with cheap credit. Until 1960, cooperative banks used various names, such as credit unions, savings and loan cooperatives, commune savings cooperatives, people's banks. Currently, a joint-stock company, state-owned enterprise, and cooperative bank are legal forms of banking activity provided for in the Polish Banking Law [Rosa, 2010, pp. 198-207; 2012, pp. 265-266].

A cooperative bank is a bank and a cooperative at the same time, which decisively affects its activities. The definition of the bank is stipulated in the Banking Law, and the definition of the cooperative - in the Cooperative Law [Cioch, 2011, p. 47]. According to this definition and principles defined by the International Cooperative Congress, the fundamental objective of a cooperative bank's operations should be financial support of the members, by offering comprehensive assistance and high quality services at good prices [Orzeszko, 1998, p. 17]. It does not exclude achieving profit, all the more so that the competitive pressure forces cooperative banks to expand their client base.

Having obtained a banking license from the Polish Financial Supervision Authority (PFSA), a cooperative bank may perform almost all activities enumerated in Art. 5 of the Banking Law, with the proviso that some of those activities it may perform for clients who live, conduct business, have a registered office or organisational unit within the bank's geographical area of operation. According to 
the Act on Cooperative Banks, a cooperative bank may grant or confirm a bank guarantee or a surety in the scope and manner agreed with its affiliating bank, and to perform some activities referred to in Art. 5 or any activity referred to in Art. 6(1) of the Banking Law, a cooperative bank needs its affiliating bank's prior consent.

The Banking Law prevents a cooperative bank from independently perform the following operations: financial forward transactions, transactions in warrants, opening and confirming letters of credit and issuing electronic money instruments (but a cooperative bank may settle and cancel e-money instruments). Most recently, in the Act Amending the Act on Cooperative Banks, cooperative banks have been authorised to issue bank securities and contract liabilities under securities in issue, upon the affiliating bank's prior consent.

The sector of cooperative banking is a permanent feature of the Polish financial system and it has shown a great ability to adjust to the changing economic conditions [Szambelańczyk, 2006]. As late as in 1989 there were 1,662 cooperative banks in Poland, with a total number of 2,577 thousand members. However, this figure has reduced during the past 28 years due to market changes (liquidations, mergers and acquisitions). The sector's major asset in Poland is that it has the most numerous bank network with 558 banks, around one million shareholders, and 2,5 million clients. The number of cooperative bank outlets, including their head offices, was 4,633 as at the end of 2016 [Nastarowicz, 2017, p. 28].

Currently, there are two affiliations of cooperative banks in Poland: the BPS Group and the Cooperative Bank Group (Spółdzielcza Grupa Bankowa). The BPS Group consists of 355 cooperative banks and its affiliating bank is BPS S.A. with its registered office in Warsaw. The BPS Group's network covers more than half of Poland.

The other affiliation operating in the Polish sector of cooperative banking is the Cooperative Bank Group. Its affiliating bank is SGB-Bank S.A. SGB consists of 203 cooperative banks. Additionally, the Cooperative Bank of Kraków (Krakowski Bank Spółdzielczy) and the Cooperative Bank of Brodnica (Bank Spółdzielczy w Brodnicy) operate as non-affiliated banks. The key objective of the BPS Group is to support regional and local growth.

Cooperative banks have recorded a continued upward trend in lending activity and changes in the loan portfolio structure. The growth rate for consumer loans decelerated to 3.8\% year on year at the end of December 2016. Year-on-year dynamics of residential loans remained high at $17.8 \%$; the share of residential loans in cooperative banks' loans to non-financial sector is relatively low at $14 \%$. There was a slowdown of the dynamics in the segment of loans to businesses $(1.1 \% \mathrm{y} / \mathrm{y})$, which was primarily attributable to the largest cooperative banks. The distinctive feature of those largest banks was a high share of loans to business in the balance-sheet structure. The annual growth rate for loans to sole proprietors remained at a similar level (1.2\%) and to independent farmers went down to $1 \%$. 
Cooperative banks saw a significant deterioration of the quality of loans to businesses, but almost exclusively at large institutions. It was partially attributable to enhanced supervision and reviews of loan portfolio quality. The increase in non-performing loans brought about larger credit losses at major cooperative banks. These banks have also a low average cover of impaired loans, which indicates a potential risk of the need to recognise further impairment losses if it becomes necessary to collect debt under these loans.

Another potential driver of impairment losses at large cooperative banks is a relatively high share of loans with shorter repayment delays. Only a small percentage of these loans is qualified as impaired; accordingly, impairment losses on them are low. An additional risk is a relatively high concentration of loan portfolio.

The profitability of the cooperative banking sector in the second half of 2017 remained approximately unchanged. A few-year-long downward trend of profitability ratios stopped. Also the diversity of asset profitability deteriorated. Key data describing the situation of cooperative banks in Poland is presented in Table 3.

Table 3. Financial highlights of the cooperative banking sector in Poland in 2017-2018, in PLN bn and \%

\begin{tabular}{|l|c|c|}
\hline \multicolumn{1}{|c|}{ Item } & 31 Dec 2017 & 31 Dec 2018 \\
\hline balance sheet total & 108.2 & 118.5 \\
\hline capital & $1,023.8$ & $1,119.8$ \\
\hline loans & $1,061.4$ & $1,094.9$ \\
\hline deposits & $1,029.0$ & $1,102.5$ \\
\hline profit/loss on banking operations & 54.9 & 44.8 \\
\hline ROA & 0.41 & 0.51 \\
\hline RORC & 4.5 & 5.8 \\
\hline
\end{tabular}

Source: Own elaboration based on: [BFG, 2018, pp. 2-7].

\section{Safety of investing in cooperative bonds - risk analysis}

So far, cooperative banks are the only cooperatives in Poland acquiring financing from the capital market. They may issue debt instruments in the form of bonds (see Table 4), as provided for in Art. 127(3)(2)(b) of the Banking Law, which (until 2015) provided for classifying liabilities under bonds as the bank's additional capital. The amendment to the Act on Cooperative Banks effective since 2015 prevents cooperative banks from including additional capital in the founding capital. At certain cooperative banks this can lead to the risk of founding capital falling below the required minimum. If this happens, mergers will take place. 
Table 4. The list of not-yet-matured cooperative bond issues listed on the Catalyst market as of 31 December 2011

\begin{tabular}{|c|c|c|c|c|c|}
\hline Bank issuer & $\begin{array}{l}\text { Bond } \\
\text { symbol }\end{array}$ & Coupon terms & $\begin{array}{c}\text { Value } \\
\text { (PLN mn) }\end{array}$ & $\begin{array}{c}\text { Redemption } \\
\text { date }\end{array}$ & $\begin{array}{l}\text { Capital } \\
\text { tier* }\end{array}$ \\
\hline $\begin{array}{l}\text { Bank Polskiej } \\
\text { Spółdzielczości S.A. }\end{array}$ & \begin{tabular}{|l|} 
BPS0720 \\
BPS0718 \\
\end{tabular} & $\begin{array}{l}\text { 6M WIBOR +3.5-5.5 p.p. } \\
\text { 6M WIBORM +3pp }\end{array}$ & $\begin{array}{r}80.0 \\
100.0\end{array}$ & $\begin{array}{l}12 \text { Jul } 2020 \\
15 \text { Jul } 2018 \\
\end{array}$ & $\mathrm{AC}$ \\
\hline $\begin{array}{l}\text { Podkarpacki Bank } \\
\text { Spółdzielczy of Sanok }\end{array}$ & \begin{tabular}{|l|} 
PBS0720 \\
PBS1021
\end{tabular} & $\begin{array}{l}6 \mathrm{M} \text { WIBOR }+4 \mathrm{pp} \\
6 \mathrm{M} \text { WIBOR }+3.2 \mathrm{pp}\end{array}$ & $\begin{array}{l}25.0 \\
23.0\end{array}$ & $\begin{array}{l}2 \text { Jul } 2020 \\
6 \text { Oct } 2021\end{array}$ & CE \\
\hline $\begin{array}{l}\text { Bank Spółdzielczy } \\
\text { of Ostrów Mazowiecka }\end{array}$ & BOM0221 & $6 \mathrm{M}$ WIBOR +3.5-4pp & 10.0 & 11 Feb 2021 & $\mathrm{AC}$ \\
\hline $\begin{array}{l}\text { Spółdzielczy Bank } \\
\text { Rozwoju of Szepietowo }\end{array}$ & \begin{tabular}{|l|} 
SBR0325 \\
SBR0725 \\
\end{tabular} & $\begin{array}{l}\text { 6M WIBOR +3.5pp } \\
6 \mathrm{M} \text { WIBOR }+3.5 \mathrm{pp} \\
\end{array}$ & $\begin{array}{l}2.0 \\
5.0\end{array}$ & \begin{tabular}{|l|}
12 Mar 2025 \\
16 Jul 2025 \\
\end{tabular} & $\mathrm{CE}$ \\
\hline $\begin{array}{l}\text { Krakowski Bank } \\
\text { Spółdzielczy }\end{array}$ & SBK1020 & $6 \mathrm{M}$ WIBOR $+4 \mathrm{pp}$ & 20.685 & 29 Oct 2020 & $\mathrm{CE}$ \\
\hline $\begin{array}{l}\text { Bank Spółdzielczy } \\
\text { of Biała Rawska }\end{array}$ & BRB0425 & $6 \mathrm{M}$ WIBOR $+3.5 \mathrm{pp}$ & 10.0 & 9 Apr 2025 & $\mathrm{CE}$ \\
\hline $\begin{array}{l}\text { Spółdzielczy Bank } \\
\text { Rzemiosła i Rolnictwa } \\
\text { of Wołomin }\end{array}$ & BSW0721 & $6 \mathrm{M}$ WIBOR $+3.2 \mathrm{pp}$ & 10.0 & $8 \mathrm{Jul} 2021$ & $\mathrm{AC}$ \\
\hline $\begin{array}{l}\text { Polski Bank Spółdziel- } \\
\text { czy Bank of Ciechanów }\end{array}$ & \begin{tabular}{|l|} 
BSC0621 \\
BSC0620 \\
\end{tabular} & $\begin{array}{l}6 \mathrm{M} \text { WIBOR }+3 \mathrm{pp} \\
6 \mathrm{M} \text { WIBOR }+3 \mathrm{pp} \\
\end{array}$ & $\begin{array}{r}8.0 \\
10.0\end{array}$ & $\begin{array}{l}22 \text { Jun } 2021 \\
18 \text { Jun } 2020\end{array}$ & CE \\
\hline $\begin{array}{l}\text { Warszawski Bank } \\
\text { Spółdzielczy }\end{array}$ & WBS0521 & $6 \mathrm{M}$ WIBOR $+3.2 \mathrm{pp}$ & 7.0 & 27 May 2021 & $\mathrm{AC}$ \\
\hline $\begin{array}{l}\text { Bank Spółdzielczy } \\
\text { of Skierniewice }\end{array}$ & BSS0418 & $6 \mathrm{M}$ WIBOR $+3.5 \mathrm{pp}$ & 8.0 & 1 Apr 2018 & $\mathrm{AC}$ \\
\hline $\begin{array}{l}\text { Mazowiecki Bank Spól- } \\
\text { dzielczy of Łomianki }\end{array}$ & MBS0720 & $6 \mathrm{M}$ WIBOR $+3.2 \mathrm{pp}$ & 8.0 & $23 \mathrm{Jul} 2020$ & $\mathrm{CE}$ \\
\hline $\begin{array}{l}\text { Podlasko-Mazurski Bank } \\
\text { Spółdzielczy of Zabłudów }\end{array}$ & PMS0624 & $6 \mathrm{M} \mathrm{WIBOR}+3 p p$ & 5.0 & 18 Jun 2024 & $\mathrm{CE}$ \\
\hline $\begin{array}{l}\text { Bank Spółdzielczy } \\
\text { of Limanowa }\end{array}$ & BSL0521 & $6 \mathrm{M}$ WIBOR $+3.2 \mathrm{pp}$ & 10.0 & 13 May 2021 & $\mathrm{AC}$ \\
\hline $\begin{array}{l}\text { Bank Spółdzielczy } \\
\text { of Piątnica }\end{array}$ & ВРТ0620 & $6 \mathrm{M}$ WIBOR $+3.2 \mathrm{pp}$ & 4.0 & 11 Jun 2020 & $\mathrm{CE}$ \\
\hline $\begin{array}{l}\text { ESBANK Bank Spól- } \\
\text { dzielczy of Radomsko }\end{array}$ & ESB0725 & $6 \mathrm{M}$ WIBOR $+3 p p$ & 5.0 & $16 \mathrm{Jul} 2025$ & CE \\
\hline $\begin{array}{l}\text { Bałtycki Bank Spółdziel- } \\
\text { czy of Darłowo }\end{array}$ & BBS1226 & $6 \mathrm{M}$ WIBOR $+3 p p$ & 2.9 & 24 Dec 2026 & CE \\
\hline $\begin{array}{l}\text { Bank Spółdzielczy } \\
\text { of Piaseczno }\end{array}$ & BSP0620 & $6 \mathrm{M}$ WIBOR $+3 p p$ & 5.0 & 25 Jun 2020 & $\mathrm{CE}$ \\
\hline $\begin{array}{l}\text { Orzesko-Knurowski Bank } \\
\text { Spółdzielczy of Knurów }\end{array}$ & OKB0520 & $6 \mathrm{M}$ WIBOR $+3 p p$ & 7.0 & 28 May 2020 & CE \\
\hline $\begin{array}{l}\text { Bank Spółdzielczy } \\
\text { of Płońsk }\end{array}$ & BPL0421 & 6M WIBOR +3-3.5pp & 7.0 & 15 Apr 2021 & $\mathrm{AC}$ \\
\hline $\begin{array}{l}\text { Gospodarczy Bank } \\
\text { Spółdzielczy of Barlinek }\end{array}$ & GBS0621 & $6 \mathrm{M}$ WIBOR $+2.8 \mathrm{pp}$ & 8.75 & 10 Jun 2021 & $\mathrm{AC}$ \\
\hline
\end{tabular}

Note: CE - common equity capital; AC - additional capital.

Source: Own elaboration based on: [Catalyst, 2018; Osiecki, 2016; Pawlonka, 2012, pp. 259-260; Galbarczyk, 2012, pp. 232-234]. 
As a rule, cooperative banks issue bonds in pursuing their business defined in the articles of association (development of lending activity), investing in branch network or innovative technological solutions, restructuring/diversifying financing sources, restructuring maturity structure for liabilities, restructuring liability revaluation dates, or increasing regulatory capital.

Figure 2 illustrates the process of primary issue of cooperative bonds. In secondary trade, bonds can be purchased on an organised secondary market, i.e. in the Catalyst system (see Figure 3).

Figure 2. Primary market of cooperative bonds

Source: Own elaboration.

The Warsaw Stock Exchange (WSE) operates two platforms in the Catalyst system: a regulated market and an Alternative Trading System (ATS). ATS supports exclusively transactions in debt instruments, excluding instruments issued by the State Treasury and the National Bank of Poland (NBP).

Regulated OTC market (ATS) is operated by BondSpot - a WSE-owned company and a segment of the Catalyst system. Here, transactions may be executed exclusively in debt securities whose total nominal value of an issue is at least PLN 5 mn and at least one market participant acts as a market maker for the issue, under an appropriate agreement with the issuer.

The instruments traded in in the ATS are cooperative bonds, covered bonds, corporate bonds, and municipal bonds with a total nominal value of the issue of at least PLN $5 \mathrm{mn}$ and with unrestricted marketability. When introducing bonds to ATS, the issuer is obliged to conclude an agreement with a market maker. 


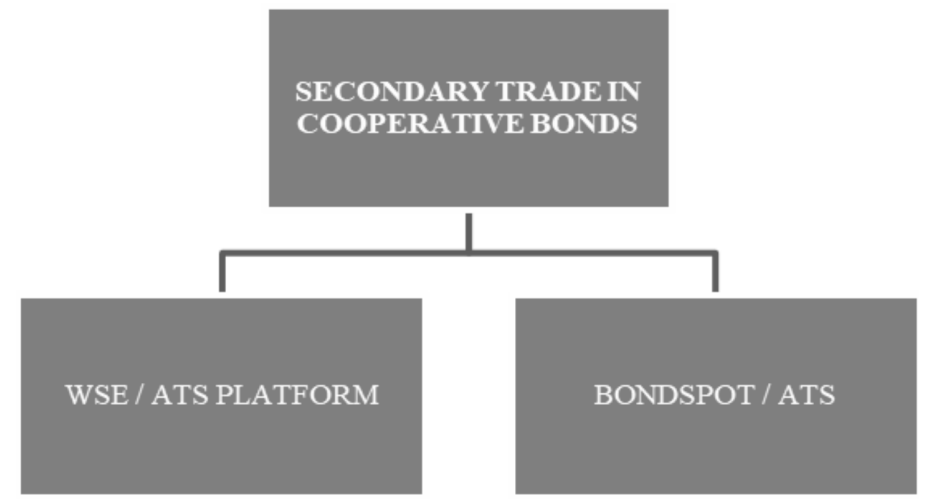

Figure 3. Secondary market of cooperative bonds

Source: Own elaboration.

The issue of debt instruments has to meet the following conditions [Gontarek, Dorosz, 2011, p. 15]:

- bonds may not be redeemed within five years from the issue,

- if the bank-issuer is declared bankrupt, creditors' claims under bonds rank last in the order of satisfaction,

- reimbursement of issue proceeds may in no way be secured by the bank,

- the Polish Financial Supervision Authority determines the amount and rules of qualifying issue proceeds as subordinated debt, with the proviso that the amount is reduced by $20 \%$ of its original value at the end of each year of outstanding,

- subordinated debt may not represent more than $50 \%$ of the common equity capital.

Bonds to be introduced to the Catalyst system should be bearer bonds in a book-entry form, as any securities admitted to exchange trading. Thanks to that, from the issue date to the redemption date, such bonds can change the holder repeatedly. A bond issue admitted to trading in the Catalyst system is registered with the Central Securities Depository of Poland (Krajowy Depozyt Papierów Wartościowych), and purchase and sale transactions are executed exclusively through brokerage houses and offices. Bonds admitted to trading in the Catalyst system are significantly more attractive for investors, as it makes them easier to resell, thus increasing the liquidity of such an investment instrument. Moreover, sale and purchase transactions on the Catalyst market are safe and executed at market prices.

As at the end of 2011, bonds issued by 19 cooperative banks were traded (see Table 4). As 574 cooperative banks operated then, the banks-issuers represented less than $3.3 \%$ of the total number. In terms of equity, the total issue proceeds (PLN $201.3 \mathrm{mn}$ ) represented $2.6 \%$ of the cooperative banks' total equity (PLN 7,751.9 mn) [Galbarczyk, 2012, p. 234]. 
Redemption periods for cooperative banks' bonds are very long, ranging from slightly over 9 years to almost 15 years. The nominal value of all those securities is PLN 1,000 per bond. The bear interest (paid semi-annually) at a variable interest rate indexed to the $6 \mathrm{M}$ WIBOR plus a fixed margin (between 3\% and 4\%). At the end of 2010, the highest interest rates were recorded for bonds issued by PBS of Sanok $(8.00 \%)$, BS of Biała Rawska (7.54\%), and SBR of Szepietów (7.50\%). In 2011, they were: KBS of Kraków (8.92\%), BS of Sanok (8.75\%), and BS of Skierniewice $(8.36 \%)$. The first two of the banks listed above offered the highest interest margin of $400 \mathrm{bp}$. In the same period, BS of Barlinek offered the lowest margin at 280bp. The other margins were in the range $300-500 \mathrm{bp}$. When assessing the profitability of cooperative bonds it should be noted that the difference between margins offered by individual issuers does not, as a rule, exceed $100 \mathrm{bp}$, which indicates that cooperative bank bonds form a practically homogeneous group of assets. Furthermore, their profitability is generally lower than the profitability of corporate bonds (where the interest rate on the issue date is usually between $8 \%$ and $15 \%$ ) [Buszko, Kołowska, 2012, pp. 253 254].

When assessing the investments in cooperative bonds issued in 2011, it should be emphasised that, due to a lack of security and very long redemption periods, these instruments will expose investors to a serious risk in a multi-year time horizon. Given this drawback, the target group for cooperative bank securities, at least in the initial stage of the development of Polish private debt market, will be qualified investors (financial institutions or specialised investment funds). If an offering of cooperative bonds has to be attractive to such investors, it must be feasible for them, relatively easily, quickly and at low cost, to liquidate these assets on the secondary market. Thus the Catalyst market will be the target trading venue.

Issuing bonds representing subordinated debt allows cooperative banks to better exploit their growth potential. As already mentioned, until 2015, according to the then applicable law, cooperative banks were allowed to qualify bond issue proceeds to common equity capital or additional capital (see Table 4), and thus improve their capital adequacy without changing the shareholding structure. This pushed up the capital adequacy ratio and provided additional capital supporting the development of lending activity and thus better address clients' needs and possibly to augment the client base. Incompetent use of common equity and additional capital by cooperative banks generated the risk of losing the capital. An example here is the investment by some of cooperative banks in Ganta corporate bonds (issues arranged by BPS). If the issuer delays interest payment, the investor has to recognise a loss on bonds, which affects the cooperative bank's profit/loss. It is also worth mentioning that the majority of cooperative bank bonds are subordinated bonds, issued mainly in 2010 and maturing in ten years. For the five years before maturity date, these bonds must be amortised at an annual rate of $20 \%$. 
Hence, since 2015, some cooperative banks disclose lower additional capital and thus record lower capital adequacy ratios and are exposed to higher operational risk.

Key risks related to investing in cooperative bonds can be classified in the following groups (see Figure 4):

- risk of a bank's creditworthiness deterioration - bankruptcy risk,

- risk of destabilisation of the cooperative banking system,

- liquidity risk,

- (independent of the issuer) macroeconomic risks, interest rate risk.

Within particular groups, detailed risks have been specified: risk of the issuer's bankruptcy, risk of volatility of the market price of bonds, risk related to the specific nature of a small bank, risk of lending activity discontinuation, risk of ineffective valuation of chosen bond series, interest rate risk, liquidity risk, risk of destabilisation of the cooperative banking system, risk of a bank's creditworthiness deterioration - bankruptcy risk, risk of lack of proper security of cooperative bonds, risk of a long redemption period, risk of losing bond issue proceeds, macroeconomic risks, interest rate risk and bonds duration, the issuer's debt, profitability against the issuer's debt.

In case of problems resulting from low interest rates, deposit interest rates, especially for time deposits, were adjusted to changes in the reference rate, but later than at commercial banks. It brought about a decrease in cooperative banks' interest margin, i.e. the difference between interest income and interest expense. This obviously affected banks' profitability, deteriorating their performance. Cooperative banks estimate that each year they can lose $10 \%$ of profit for that reason.

From the investment perspective, cooperative banks' bonds will be exposed to most risks connected with corporate bonds, including primarily risk of the issuer's (bank's) bankruptcy, interest rate risk, liquidity risk or risk of bond market price volatility. Nevertheless, in relation to cooperative bonds qualifying as common equity capital under the PFSA's decision, several additional risks appear, especially when in time of an economic downward trend, the bank's bankruptcy or liquidation. If the issuer's financial standing has deteriorated materially, the payment of interest or redemption of bonds (payment of bond principal) may delay. If the issuer is declared bankrupt or is liquidated, bondholders' claims will rank last in the order of satisfaction.

Further, an early redemption of these bonds will be possible only after ten years of the issue closing date. Similar investment risk factors will have to be taken into consideration in case of bonds qualifying as additional capital, where the capital under bonds may be redeemed only after five years, bondholders' claims will rank last in the order of satisfaction and no security, whether direct or indirect, for such bonds will be permitted [Buszko, Kołowska, 2012, p. 251].

The risk of a small bank's specific nature directly relates to the aforementioned process. From a bondholder's perspective, purchasing subordinated bonds means 
that if the cooperative bank-issuer is declared bankrupt, the investor will be treated not like a standard creditor but rather like a shareholder. It will receive the invested money only when all other claims against the bankrupt bank are satisfied.

It is worth noticing that cooperative banks' situation is worse than commercial banks'. Several factors contribute to this. First, in the case of cooperative banks, the share of commission income in the total profit is much smaller, which, given low interest rates, significantly affects profitability. Secondly, lower capital adequacy pose the risk of discontinuing lending activity, when capital adequacy and liquidity ratios fall below the respective threshold levels.

The risk related to cooperative bonds issue also entails the danger of ineffective market valuation of selected bonds series. This may stem from the fact that the investors who have acquired the bonds of selected series in the initial offering are not willing to sell them on the secondary market. The price differences between individual bond series can result from the fact that a large institutional investor has acquired a substantial block of bonds of a given series and does introduce the bonds to trading, which, given low liquidity of the secondary market, pushes the listed price of the series well above the prices of other series. Also a price reduction can result from low liquidity, when a large bondholder disposes of a given series.

\section{Study of the safety of investing in cooperative bonds in Fisher-Weil model, risk indicators and findings}

The conducted research into the safety of cooperative bonds was based on:

1. risk indicators: issuer's debt (ID) ${ }^{1}$ and profitability against the issuer's debt (PID) ${ }^{2}$,

2. average duration $\mathrm{D}$,

3. convexity $\mathrm{V}$.

The present value (corresponding market price) of a bond may be subject to continuous and unexpected fluctuations due to changes in market interest rates prevailing at a given time and used in discounting all future cash inflows related to the bond holding over time. Changes in market interest rates are often difficult

1 The issuer's debt is decidedly the most important indicator of the potential risk to which the issuer's future ability to service his debt is exposed. Low debt means investment in bonds is safe. An entity whose liabilities represent less than half of the assets is characterised by a risk relatively lower than an entity with a higher liabilities to assets ratio. If the ratio is in the range from 0.5 to 0.75 , we speak of an increased risk. If the debt to assets ratio goes above $75 \%$, the risk of investing in bonds is very high.

2 No risk analysis for investing in bonds is deemed reasonable without testing profitability against the issuer's debt. The debt to EBITDA ratio says how much time an entity would need to repay its debt (EBITDA is the most often used metric of earnings). If the ratio stood at 2.5, it would mean that an entity allocating the entire EBITDA to debt repayment would need approximately 2.5 years to repay the entire debt; this is considered a relatively safe level. The ratio above 3 indicates increased risk. Ratio exceeding 5 is in numerous cases unacceptable. 
to predict, while the resulting changes in bond prices are a source of risk for the both investor and issuer. This risk is reflected in what is known as 'unanticipated return' [Elton et al., 2003]. Therefore, for the both investor and issuer, the sensitivity of bond price to changes in market interest rates is material. The parameters enabling such sensitivity to be measured are the average duration $\mathrm{D}$ and convexity $\mathrm{V}$ of bonds. The duration is the weighted average waiting period for cash inflows from bonds. The modified duration informs how much the bond price will change (with change expressed in percent) if the market interest rate changes by 1 percentage point. One should remember that the directions of changes in the interest rate and the price are opposite, i.e. an increase in the interest rate drives the price of bonds down, while a decrease in the interest rate pushes the price of bonds up.

The bond duration is determined according to the following formula:

$$
D=\frac{\frac{1 C 1}{(1+r)^{1}}}{P}+\frac{\frac{2 C 2}{(1+r)^{2}}}{P}+\frac{\frac{3 C 3}{(1+r)^{3}}}{P}+\ldots+\frac{\frac{n(C n+W)}{(1+r)^{n}}}{P}=\frac{\frac{n(i \cdot C i)}{(1+r)^{i}}}{P}+\frac{\frac{n \cdot W}{(1+r)^{n}}}{P}
$$

where:

$D$ - bond duration,

$P$ - bond price,

C1, C2, C3, Cn - interest coupons payable in consecutive periods,

$W$ - nominal value of bonds (received at redemption),

$R$ - market interest rate,

$N$ - number of years to maturity.

The following formula enables the change in the bond price in response to the change in the interest rate to be calculated:

$$
\Delta P=P \cdot \frac{-D}{1+r} \cdot \Delta r+-P \cdot D z \cdot \Delta r
$$

where:

$D$ - bond duration,

$D z$ - bond modified duration,

$P$ - bond price,

$R$ - market interest rate,

$\Delta P$ - change in bond price,

$\Delta r$ - change in interest rate,

$N$ - number of years to maturity.

For the purposes of this analysis, a modified Fisher-Weil model was used to manage the bond portfolio exposed to the risk of unexpected interest rate changes and the risk of yield curve shape change [Fisher, Weil, 1971, pp. 408-431; Jakubowski, 2012]. 
The following assumptions were adopted:

- all market interest rates and their increments are equal,

- interest is compounded continuously,

- current value of bonds: $P=\frac{C}{1+r_{1}}+\frac{C}{\left(1+r_{2}\right)^{2}}+\ldots+\frac{C}{\left(1+r_{T}\right)^{T}}+\frac{N}{\left(1+r_{T}\right)^{T}}$

$-C_{t}=C$, where: $\mathrm{t}=1 . . T ; C_{T}=C+N ; d r_{t}=d r$, where: $\mathrm{t}=1 . . T ; r_{1}, \ldots, r_{t}, \ldots, r_{T}$ are pairwise different,

$-(1+r)^{-t}=\exp \left(-r_{t} \cdot t\right)$,

$-x_{t}=\Delta C_{t} e^{-r t} / P$,

$-\frac{d P}{P}=-D \cdot d r+V \cdot(d r)^{2}$

- $d P / P$ is the unanticipated return on bonds due to unexpected changes $d F_{f}(f=1$, $\ldots, m)$,

$-\mathrm{X}=r_{\tau t}$ is the interest rate observation matrix, $r_{t}=(t=1, \ldots, T)$,

$-\tau=1, \ldots, T$ are consecutive time instants,

- $T S_{(\tau)}$ are vectors-rows, where: $T S_{(\tau)}=r_{1}(\tau), \ldots, r_{t}(\tau), \ldots, r_{T}(\tau)=r_{\tau 1}, \ldots, \mathrm{r}_{\tau 1}, \ldots, \mathrm{r}_{\tau t}, \ldots, \mathrm{r}_{\tau T}$. Formula for the present value of bonds then takes the following form:

$$
P=P_{(r)}=P\left(r_{1} \ldots r_{\tau 1} \ldots r_{T}\right)=\sum_{t-1}^{\tau} C t \exp (-r t \cdot t)
$$

Upon approximating the increment $d P$ of function (3), we get:

$$
\begin{aligned}
d P=P(r+d r)-P(r)= & \sum_{t-1}^{\tau} \frac{\partial P}{\partial r_{t}} d r_{t}+\frac{1}{2} \sum_{t-1}^{\tau} \frac{\partial^{2} P}{\partial r_{t}^{2}}\left(d r_{t}\right)^{2}=\sum \frac{\tau}{t-1}\left(t C_{t} e^{-\tau t}\right) \\
& d r_{t}+\frac{1}{2} \sum_{t-1}^{\tau}\left(t^{2} C_{t} \partial^{-r t}\right)\left(d r_{t}\right)^{2}
\end{aligned}
$$

Dividing both sides of formula (4) by $\mathrm{P}$, we obtain:

$$
\frac{d P}{P}=\left(-\sum_{t-1}^{\tau}\left(t C_{t} e^{-r t} / P\right) d r+\frac{1}{2}\left(\sum_{t-1}^{\tau}\left(t^{2} C_{t} e^{-r t} / P\right)\left(d r_{t}\right)^{2}\right.\right.
$$

Transforming formula (5), we get: D (formulae 6 and 7) and V (formulae 8 and 9):

$$
\begin{gathered}
D=\Delta \sum_{\tau-1}^{\tau} t C_{t} e^{-r t} / P=\sum_{t-1}^{\tau} x_{t} t \\
D=\sum_{t-1}^{\tau} \frac{\partial P}{\partial r_{t}} \frac{1}{P} \\
V=\Delta \frac{1}{2} \sum_{t-1}^{\tau} t^{2} C_{t} e^{-r t} / P \\
V=\Delta \frac{1}{2} \sum_{t-1}^{\tau} \frac{\partial^{2} P}{\partial r_{t}^{2}} \frac{1}{P} \\
\frac{d P}{P}=-\sum_{f=1}^{m} D_{f} d F_{f}+\sum_{f=1}^{m} V_{f}\left(d F_{f}\right)^{2}
\end{gathered}
$$


A

ת

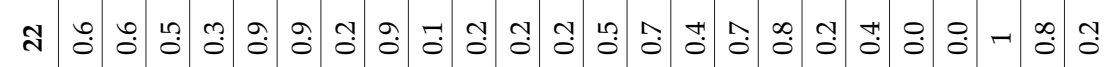

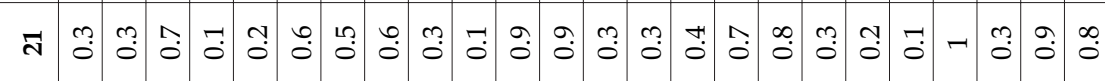

กิ

2 2

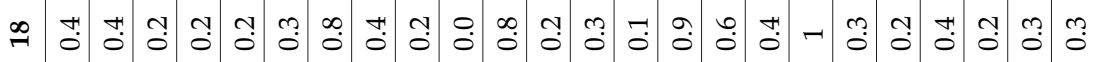

A

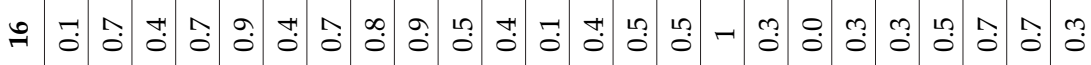

L

\#

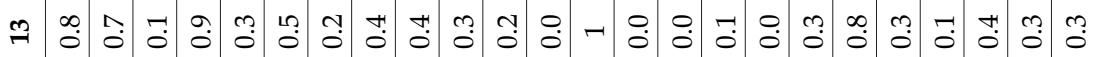

I

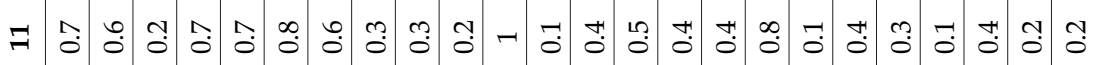

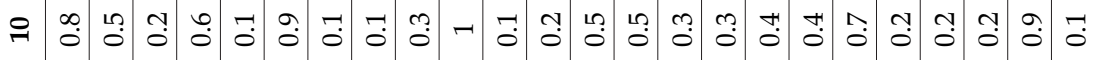

a

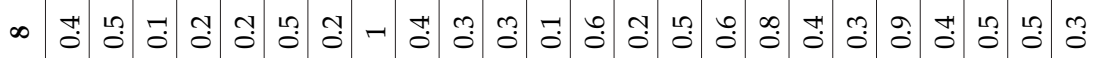

几

○

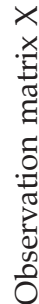

L

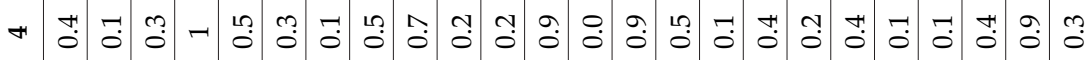

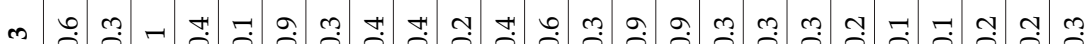

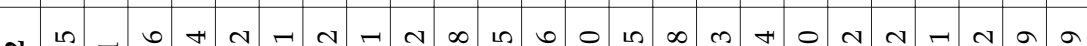

N 


\begin{tabular}{|c|c|c|c|c|c|c|c|c|c|c|c|c|c|c|c|c|c|c|c|c|c|c|c|c|}
\hline तี & -1 & $\Lambda$ & $\Lambda$ & 0 & 10 & $\infty$ & 0 & $a$ & $N$ & - & $\Lambda$ & + & $\mathrm{N}$ & - & 0 & - & - & -1 & م & 6 & -1 & $\infty$ & $F$ & - \\
\hline$\ddot{N}$ & - & N & $\mathrm{N}$ & $a$ & + & $\wedge$ & $a$ & $a$ & $\mathrm{~N}$ & - & $\psi$ & $\infty$ & $N$ & $\mathrm{~N}$ & 0 & - & $\mathrm{N}$ & $m$ & $\psi$ & 0 & $\mathrm{~N}$ & $\Lambda$ & - & - \\
\hline ส & - & $\infty$ & $\Lambda$ & 0 & + & 0 & مו & $a$ & $\mathrm{~N}$ & $\infty$ & $\infty$ & $N$ & $N$ & - & $\mathrm{N}$ & $\infty$ & $\infty$ & $a$ & $\infty$ & 10 & -1 & - & $N$ & -1 \\
\hline ה & - & $m$ & $\mathrm{~N}$ & م & $\infty$ & $\psi$ & 10 & $a$ & 0 & + & $\mathrm{N}$ & -1 & $\mathrm{~N}$ & 10 & - & $N$ & 10 & $\infty$ & $N$ & $H$ & - & - & - & N \\
\hline శి & $\neg$ & N & + & $H$ & $N$ & $\infty$ & $\psi$ & $\wedge$ & 10 & $\infty$ & $\neg$ & -1 & $m$ & + & 6 & $a$ & $\psi$ & $\wedge$ & -1 & - & 10 & + & $\infty$ & $\infty$ \\
\hline$\stackrel{2}{2}$ & 0 & مו & 10 & $\infty$ & 0 & $N$ & $\infty$ & $\neg$ & H & $N$ & م & $N$ & $a$ & $\infty$ & م & $\infty$ & $\infty$ & 0 & 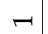 & $\mathrm{N}$ & H & 10 & $N$ & 4 \\
\hline$\stackrel{\infty}{\sim}$ & $m$ & $\gamma$ & 6 & $N$ & $a$ & $a$ & $\mathrm{~N}$ & 0 & $m$ & $\Lambda$ & 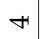 & $\infty$ & 6 & $N$ & 4 & $\Lambda$ & 0 & -1 & $\Lambda$ & $\infty$ & $\infty$ & + & -1 & $\mathrm{~N}$ \\
\hline$\underline{-}$ & $\checkmark$ & 6 & $\Lambda$ & $\infty$ & $\infty$ & $\infty$ & + & 10 & $N$ & 0 & $\infty$ & $\mathrm{N}$ & 10 & 0 & $\infty$ & 0 & - & مו & 6 & $\infty$ & $\infty$ & $\infty$ & $\mathrm{N}$ & - \\
\hline$\stackrel{0}{-1}$ & 0 & $\infty$ & $\mathrm{N}$ & $\infty$ & + & $\wedge$ & $\infty$ & $H$ & $a$ & ما & $\mathrm{N}$ & $a$ & +1 & $a$ & $\mathrm{~N}$ & -1 & $\psi$ & $\psi$ & مו & $\infty$ & - & $\mathrm{N}$ & - & $H$ \\
\hline$\stackrel{10}{\sim}$ & $H$ & $a$ & $\Lambda$ & $\infty$ & $n$ & 0 & $\mathrm{~N}$ & $m$ & $\infty$ & + & 0 & $\infty$ & $m$ & $\infty$ & -1 & $H$ & $m$ & - & $\psi$ & $\infty$ & - & - & $N$ & 6 \\
\hline 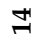 & $m$ & $\mathrm{~N}$ & + & $\wedge$ & $N$ & $m$ & $a$ & $\mathrm{~N}$ & $\Lambda$ & $\infty$ & $a$ & $\Lambda$ & $\mathrm{N}$ & -1 & $N$ & + & $N$ & -1 & $\infty$ & $\infty$ & 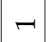 & $\infty$ & $\infty$ & 10 \\
\hline 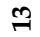 & - & $\mathrm{N}$ & $m$ & $N$ & $\Lambda$ & $a$ & + & 0 & 6 & - & $\infty$ & 6 & - & -1 & 10 & 0 & $\rightarrow$ & - & $N$ & $n$ & - & $\Lambda$ & 10 & + \\
\hline$\stackrel{N}{\sim}$ & $\infty$ & $\psi$ & $N$ & $\infty$ & 6 & - & $n$ & $a$ & م & -1 & $\Lambda$ & -1 & 0 & $N$ & H & 10 & $\infty$ & 0 & -1 & $n$ & 0 & 6 & H & $\infty$ \\
\hline$F$ & 6 & $\infty$ & 0 & + & + & - & $\mathrm{N}$ & $m$ & + & - & -1 & $N$ & 10 & $\infty$ & 0 & $\infty$ & $\Lambda$ & 10 & -1 & $\infty$ & 10 & 10 & $\infty$ & $\mathrm{N}$ \\
\hline 윽 & 0 & $\infty$ & -1 & 0 & $N$ & - & $\Lambda$ & $\mathrm{N}$ & $m$ & - & - & $H$ & + & + & $a$ & $N$ & 0 & 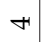 & $N$ & $\infty$ & + & 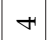 & $\mathrm{N}$ & - \\
\hline$a$ & $\sim$ & N & $a$ & -1 & $a$ & - & ما & - & -1 & ما & 0 & $\infty$ & $\infty$ & 10 & $\Lambda$ & -1 & 10 & $\infty$ & 6 & $\infty$ & $\infty$ & $\infty$ & H & - \\
\hline$\infty$ & - & $\Lambda$ & + & -1 & + & - & $m$ & - & - & ما & 10 & $\mathrm{~N}$ & $N$ & 6 & ما & $\infty$ & $\psi$ & $\mathrm{N}$ & ما & $\infty$ & $\mathrm{N}$ & + & $\infty$ & $\mathrm{N}$ \\
\hline$\Lambda$ & 0 & $N$ & $\infty$ & $\neg$ & $N$ & 0 & - & 10 & $\mathrm{~N}$ & م & ما & -1 & - & $\infty$ & 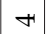 & $N$ & $\infty$ & - & $H$ & $\mathrm{~N}$ & - & 0 & H & $\infty$ \\
\hline 0 & $a$ & 0 & $\mathrm{~N}$ & - & $N$ & -1 & $\infty$ & 0 & $H$ & $N$ & 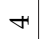 & $\Lambda$ & $\infty$ & $a$ & $\infty$ & - & $\mathrm{N}$ & 6 & $N$ & $\mathrm{~N}$ & $a$ & $a$ & $\infty$ & $\mathrm{N}$ \\
\hline 10 & 10 & N & $\infty$ & $N$ & -1 & $\infty$ & مו & $a$ & $m$ & $\infty$ & $\mathrm{N}$ & 6 & $\Lambda$ & $\infty$ & $\mathrm{N}$ & $\Lambda$ & $\infty$ & 0 & $\infty$ & $\mathrm{N}$ & $\infty$ & $\infty$ & $\Lambda$ & $\infty$ \\
\hline H & $\mathrm{N}$ & $m$ & $\mathrm{~N}$ & - & $\infty$ & 6 & $\psi$ & $a$ & N & $\infty$ & $\infty$ & ما & 6 & $\infty$ & 6 & 0 & $\triangle$ & مו & $\Lambda$ & $\Lambda$ & $\Lambda$ & $\Lambda$ & 6 & $\Lambda$ \\
\hline$m$ & + & $\mathrm{N}$ & -1 & $a$ & $\wedge$ & 10 & $\infty$ & + & 10 & $\infty$ & 10 & $H$ & 10 & $N$ & 10 & 10 & 0 & $\psi$ & 6 & 6 & 6 & 6 & م & 0 \\
\hline$N$ & - & $\neg$ & $m$ & $N$ & 0 & + & $N$ & $m$ & 10 & + & 0 & $m$ & + & $N$ & H & $H$ & 10 & $\infty$ & | & 10 & | & 10 & H & 10 \\
\hline-1 & - & $N$ & -1 & -1 & $\pi$ & $m$ & -1 & $N$ & in & () & 10 & $N$ & $n$ & $\mathbf{N}$ & $m$ & $\infty$ & $\pi$ & $\mathbf{N}$ & $\theta$ & + & $H$ & $\theta$ & $m$ & H \\
\hline
\end{tabular}


For the purpose of this study, matrix $X$ was created, where market interest rates are random variables.

The matrix is built as follows: the column $t$ presents the realisations of the random variable $r_{t}$ at consecutive $\tau=1, \ldots, M$. The rows of this matrix are defined by the vectors-rows. On the basis of values of individual columns of the observation matrix $X$, the estimators were determined for covariance coefficients $\sigma_{t 1}$ and correlation coefficients $\rho_{t 1}$ between interest rates $r_{t}$ and $r_{1}$. These coefficients build the covariance matrix $R$ and the correlation matrix $Q$, respectively (see Table 5 and Table 6).

The strength of correlation in risk was determined using the Stanisz scale (SC) [Stanisz, 1998, pp. 34-43) ${ }^{3}$ :

- (level 1) If $r_{x y}=0$, we say that the variables are not correlated.

- (level 2) If $0<r_{x y} \leq 0.1$, we say that the variables are hardly correlated; the coefficient is almost insignificant.

- (level 3) If $0.1<r_{x y} \leq 0.3$, we say that the variables are weakly correlated; the coefficient is clearly visible, but low.

- (level 4) If $0.3 \leq r_{x y} \leq 0.5$, we say that the variables are averagely correlated; the coefficient is meaningful (real).

- (level 5) If $0.5 \leq r_{x y} \leq 0.7$, we say that the variables are highly correlated; the coefficient is material.

- (level 6) If $0.7 \leq r_{x y} \leq 0.9$, we say that the variables are very highly correlated; the coefficient is substantial.

- (level 7) If $0.9 \leq r_{x y} \leq 1$, we say that the correlation is almost certain; the coefficient is certain.

- (level 8) >1, we say that the correlation is certain; the coefficient is high. The conducted studies have shown that in the case of analysed cooperative bonds (Table 4 and Table 7), the following correlations have an impact on the level of investment and portfolio risk (relations) (see Figure 4):

1. duration and convexity of the bond portfolio are combinations of convex duration parameters and protuberance of particular bonds included in the portfolio: BPS0720, BPS0718, PBS0720, PBS1021, BOM0221, SBR0325, SBR0725, SBK1020, BRB0425, BSW0721, BSC0621, BSC0620, WBS0521, BSS0418, MBS0720, PMS0624, BSL0521, BPT0620, ESB0725, BBS1226, BSP0620, OKB0520, BPL0421, GBS0621,

2. there is an inverse relationship between duration and bond interest rate (with the same yield rate and maturity date): GBS0621, BSC0621, BSC0620, PMS0624, ESB0725, BBS1226, BSP0620, OKB0520,

3. there is a direct proportional relationship between duration and maturity of bonds (with the same interest rate and yield): BPS0720, BPS0718, PBS0720,

3 The choice of the Stanisz scale was dictated by the correlation between ID and PID. 
PBS1021, BOM0221, SBR0325, SBR0725, SBK1020, BRB0425, BSW0721, BSC0621, BSC0620, WBS0521, BSS0418, MBS0720, PMS0624, BSL0521, BPT0620, ESB0725, BBS1226, BSP0620, OKB0520, BPL0421, GBS0621,

4. interest payments give rise to a slight increase in duration: BPS0720, BPS0718, PBS0720, PBS1021, BOM0221, SBR0325, SBR0725, SBK1020, BRB0425, BSW0721, BSC0621, BSC0620, WBS0521, BSS0418, MBS0720, PMS0624, BSL0521, BPT0620, ESB0725, BBS1226, BSP0620, OKB0520, BPL0421, GBS0621,

5. an increase (decrease) in the rate of return (market interest rates) results in shortening (extension) the duration of the term: BPS0720, BPS0718, PBS0720, PBS1021, BOM0221, SBR0325, SBR0725, SBK1020, BRB0425, BSW0721, BSC0621, BSC0620, WBS0521, BSS0418, MBS0720, PMS0624, BSL0521, BPT0620, ESB0725, BBS1226, BSP0620, OKB0520, BPL0421, GBS0621,

6. the convexity of the modified duration to changes in the coupon rate is greater than to changes in the rate of return: BPS0720, BPS0718,

7. the more distant the maturity date is, the greater the duration, but the rate of increase in duration is decreasing: BPS0720, BPS0718, PBS0720, PBS1021, BOM0221, SBR0325, SBR0725, SBK1020, BRB0425, BSW0721, BSC0621, BSC0620, WBS0521, BSS0418, MBS0720, PMS0624, BSL0521, BPT0620, ESB0725, BBS1226, BSP0620, OKB0520, BPL0421, GBS0621,

8. the higher the convexity, the lower the required rate of return, the longer the maturity date and the modified duration: PBS1021, BOM0221, SBR0325, SBR0725, BRB0425, BSW0721, BSC0621, WBS0521, PMS0624, BSL0521, ESB0725, BBS1226, BPL0421, GBS0621.

Table 7. Safety of cooperative bonds against the indicators ID and PID

\begin{tabular}{|l|l|c|c|l|c|l|}
\hline \multicolumn{1}{|c|}{ Bank issuer } & \multicolumn{1}{|c|}{$\begin{array}{c}\text { Bond } \\
\text { symbol }\end{array}$} & ID & PID & SC level & $\begin{array}{c}\text { Value } \\
\text { (PLN mn) }\end{array}$ & $\begin{array}{l}\text { Redemp- } \\
\text { tion date }\end{array}$ \\
\hline $\begin{array}{l}\text { Bank Polskiej } \\
\text { Spółdzielczości S.A. }\end{array}$ & $\begin{array}{l}\text { BPS0720 } \\
\text { BPS0718 }\end{array}$ & $0.1-0.5$ & 2.5 & $\begin{array}{l}\text { ID:4 } \\
\text { PID:8 }\end{array}$ & $\begin{array}{r}80.0 \\
100.0\end{array}$ & $\begin{array}{l}\text { 12 Jul 2020 } \\
\text { 15 Jul 2018 }\end{array}$ \\
\hline $\begin{array}{l}\text { Podkarpacki Bank } \\
\text { Spółdzielczy of Sanok }\end{array}$ & $\begin{array}{l}\text { PBS0720 } \\
\text { PBS1021 }\end{array}$ & $0.1-0.5$ & 2.5 & $\begin{array}{l}\text { ID:4 } \\
\text { PID:8 }\end{array}$ & $\begin{array}{r}25.0 \\
23.0\end{array}$ & $\begin{array}{l}\text { 2 Jul 2020 } \\
\text { 6 Oct 2021 }\end{array}$ \\
\hline $\begin{array}{l}\text { Bank Spółdzielczy } \\
\text { of Ostrowia Mazowiecka }\end{array}$ & BOM0221 & $0.5-0.75$ & 3.0 & $\begin{array}{l}\text { ID:5 } \\
\text { PID:8 }\end{array}$ & 10.0 & 11 Feb 2021 \\
\hline $\begin{array}{l}\text { Spółdzielczy Bank Rozwoju } \\
\text { of Szepietów }\end{array}$ & $\begin{array}{l}\text { SBR0325 } \\
\text { SBR0725 }\end{array}$ & $0.5-0.75$ & 3.0 & $\begin{array}{l}\text { ID:5 } \\
\text { PID:8 }\end{array}$ & $\begin{array}{l}2.0 \\
5.0\end{array}$ & $\begin{array}{l}\text { 12 Mar } 2025 \\
\text { 16 Jul 2025 }\end{array}$ \\
\hline $\begin{array}{l}\text { Krakowski Bank } \\
\text { Spółdzielczy }\end{array}$ & SBK1020 & $0.1-0.5$ & 2.5 & $\begin{array}{l}\text { ID:4 } \\
\text { PID:8 }\end{array}$ & 20.685 & 29 Oct 2020 \\
\hline $\begin{array}{l}\text { Bank Spółdzielczy } \\
\text { of Biała Rawska }\end{array}$ & BRB0425 & $0.5-0.75$ & 3.0 & $\begin{array}{l}\text { ID:5 } \\
\text { PID:8 }\end{array}$ & 10.0 & 9 Apr 2025 \\
\hline $\begin{array}{l}\text { Spółdzielczy Bank Rzemiosła } \\
\text { i Rolnictwa of Wołomin }\end{array}$ & BSW0721 & $0.5-0.75$ & 2.5 & $\begin{array}{l}\text { ID:5 } \\
\text { PID:8 }\end{array}$ & 10.0 & 8 Jul 2021 \\
\hline
\end{tabular}




\begin{tabular}{|c|c|c|c|c|c|c|}
\hline Bank issuer & $\begin{array}{l}\text { Bond } \\
\text { symbol }\end{array}$ & ID & PID & SC level & $\begin{array}{c}\text { Value } \\
\text { (PLN mn) }\end{array}$ & $\begin{array}{l}\text { Redemp- } \\
\text { tion date }\end{array}$ \\
\hline $\begin{array}{l}\text { Polski Bank Spółdzielczy } \\
\text { of Ciechanów }\end{array}$ & \begin{tabular}{|l|} 
BSC0621 \\
BSC0620
\end{tabular} & $0.5-0.75$ & 3.0 & \begin{tabular}{|l} 
ID:5 \\
PID:8
\end{tabular} & $\begin{array}{r}8.0 \\
10.0\end{array}$ & $\begin{array}{l}22 \text { Jun } 2021 \\
18 \text { Jun } 2020 \\
\end{array}$ \\
\hline $\begin{array}{l}\text { Warszawski Bank } \\
\text { Spółdzielczy }\end{array}$ & WBS0521 & $0.1-0.5$ & 2.5 & \begin{tabular}{|l} 
ID:4 \\
PID:8
\end{tabular} & 7.0 & 27 May 2021 \\
\hline $\begin{array}{l}\text { Bank Spółdzielczy } \\
\text { of Skierniewice }\end{array}$ & BSS0418 & $0.5-0.75$ & 2.5 & \begin{tabular}{|l} 
ID:5 \\
PID:8
\end{tabular} & 8.0 & 1 Apr 2018 \\
\hline $\begin{array}{l}\text { Mazowiecki Bank } \\
\text { Spółdzielczy of Łomianki }\end{array}$ & MBS0720 & $0.5-0.75$ & 3.0 & \begin{tabular}{|l|} 
ID:5 \\
PID:8
\end{tabular} & 8.0 & $23 \mathrm{Jul} 2020$ \\
\hline $\begin{array}{l}\text { Podlasko-Mazurski Bank } \\
\text { Spółdzielczy of Zabłudów }\end{array}$ & PMS0624 & $0.5-0.75$ & 3.0 & \begin{tabular}{|l} 
ID:5 \\
PID:8
\end{tabular} & 5.0 & 18 Jun 2024 \\
\hline $\begin{array}{l}\text { Bank Spółdzielczy } \\
\text { of Limanowa }\end{array}$ & BSL0521 & $0.1-0.5$ & 2.5 & \begin{tabular}{|l} 
ID:4 \\
PID:8
\end{tabular} & 10.0 & 13 May 2021 \\
\hline $\begin{array}{l}\text { Bank Spółdzielczy } \\
\text { of Piątnica }\end{array}$ & ВРТ0620 & $0.5-0.75$ & 3.0 & \begin{tabular}{|l} 
ID:5 \\
PID:8
\end{tabular} & 4.0 & 11 Jun 2020 \\
\hline $\begin{array}{l}\text { ESBANK Bank Spółdzielczy } \\
\text { of Radomsko }\end{array}$ & ESB0725 & $0.5-0.75$ & 3.0 & \begin{tabular}{|l} 
ID:5 \\
PID:8
\end{tabular} & 5.0 & $16 \mathrm{Jul} 2025$ \\
\hline $\begin{array}{l}\text { Bałtycki Bank Spółdzielczy } \\
\text { of Darłowo }\end{array}$ & BBS1226 & $0.1-0.5$ & 2.5 & \begin{tabular}{|l} 
ID: 4 \\
PID $: 8$
\end{tabular} & 2.9 & 24 Dec 2026 \\
\hline $\begin{array}{l}\text { Bank Spółdzielczy } \\
\text { of Piaseczno }\end{array}$ & BSP0620 & $0.1-0.5$ & 2.5 & $\begin{array}{l}\text { ID:4 } \\
\text { PID:8 }\end{array}$ & 5.0 & 25 Jun 2020 \\
\hline $\begin{array}{l}\text { Orzesko-Knurowski Bank } \\
\text { Spółdzielczy of Knurów }\end{array}$ & OKB0520 & $0.5-0.75$ & 2.5 & \begin{tabular}{|l} 
ID:5 \\
PID:8
\end{tabular} & 7.0 & 28 May 2020 \\
\hline $\begin{array}{l}\text { Bank Spółdzielczy } \\
\text { of Płońsk }\end{array}$ & BPL0421 & $0.5-0.75$ & 3.0 & \begin{tabular}{|l} 
ID:5 \\
PID:8
\end{tabular} & 7.0 & 15 Apr 2021 \\
\hline $\begin{array}{l}\text { Gospodarczy Bank } \\
\text { Spółdzielczy of Barlinek }\end{array}$ & GBS0621 & $0.5-0.75$ & 3.0 & $\begin{array}{l}\text { ID:5 } \\
\text { PID:8 }\end{array}$ & 8.75 & 10 Jun 2021 \\
\hline
\end{tabular}

Source: Own elaboration.

The security level of the analysed cooperative bonds with respect to risk ratios: issuer's debt (ID), profitability in relation to the issuer's debt (PID) and SC are presented in Table 7. Among the 20 cooperative banks surveyed, in terms of ID rate, none of the banks listed very high risk bonds (0.75-0.95), 13 banks recorded a ratio of $0.5-0.75$ (medium-risk bonds), and 7 banks recorded a ratio of 0.1-0.5 (low-risk bonds).

The PID for the analysed group of banks was as follows: none of the banks listed very high risk bonds (above 0.5 ); 10 banks recorded a level of 2.5 , which means a relatively safe level of bonds; other 10 banks recorded a PID of 3.0, which means increased risk in relation to their bonds.

The analysis of the security level of cooperative bonds in the following areas: D-average duration, V-convexity and risk indicator (on the basis of SC) ID shows that investments in the bonds under analysis are relatively secure. ID indicator for all the bonds in analysed, takes the midpoint value of the SC (for 7 banks, this is 
the level 4; for 13 banks, this is the level 5) (see Figure 4). This means an acceptable level of risk for the investor. This is due to the fact that an entity with liabilities below half the value of other assets is characterised by a relatively lower risk than the entity with a higher liability to asset ratio.

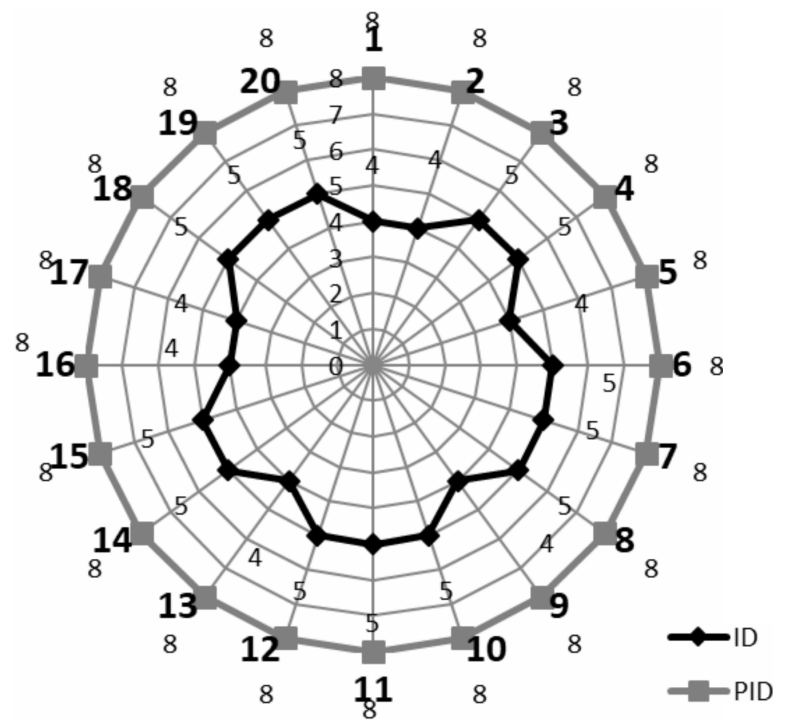

Figure 4. Level of risk of cooperative banks' bonds

Note: 1-20: number of banks.

Source: Own elaboration.

On the other hand, there is a high risk for the PID ratio (level 8 for all banks analysed). Comparison of the coverage of the annual income ratio, the value of the total debt (EBITDA) gives information on the time at which the company is able to repay the debt. The level of this ratio of indicates that the company, by allocating the entire EBITDA result to repayment of the debt, may repay the debt in a period. It should be remembered that the adopted the level of the increased risk is when it exceeds 3 and when it exceeds 5, it may be in many cases unacceptable.

\section{Conclusions}

The author believes that the conducted analysis represents an added value owing to its comprehensive nature and the taken-up subject of assessing the risk of cooperative bonds. The analysis covered all Polish cooperative bonds issued in 
2018 and maturing in 2026 . All 24 bond issues performed by 20 cooperative banks were classified against the ID and PID indicators, as well as D and V parameters.

There is relatively scant literature which would contain in-depth analysis of various types of cooperative bonds in terms of the risk involved. Therefore, the analysis performed attempts to cover this issue. The research identified general risks applicable to all cooperative bonds, as well as risks specific to each of the 24 bond issues analysed. The analysis was based on the assumed research methodology and risk classification on the Stanisz scale. The correlation of ID- and PIDrelated risks identified three risk levels for the 24 bonds analysed and classified them in two categories: levels 4 and 5 for ID and level 8 for PID. These levels are correlated with the identified values of the ID and PID indicators.

Based on the classification, the cooperative bonds were divided by type into eight groups: duration and convexity of the bond portfolio, duration and bond interest rate, duration and maturity of bonds, interest payments, increase (decrease) in the rate of return, convexity of the modified duration to changes in the coupon rate, maturity date and convexity - required rate of return - maturity date - duration.

Four groups of basic risks related to investing in cooperative bonds were specified: bankruptcy risk, risk of cooperative banking system destabilisation, liquidity risk and macroeconomic risks. Within those four groups, 16 general risks related to cooperative bonds were identified for the period 20182026 under analysis: issuer's bankruptcy, fluctuation of market price of bonds, small bank's specific nature, lending activity suspension, ineffective valuation of chosen bonds series, interest rate risk, liquidity risk, risk of cooperative banking system destabilisation, bank's creditworthiness deterioration - bankruptcy risk, lack of proper security of cooperative bonds, long redemption period, loss of proceeds from the sale of cooperative bonds, macroeconomic risks, interest rate risk and bonds duration, the issuer's debt, profitability against the issuer's debt.

Although issuing debt securities will not affect basic funds (due to changes after 2015), the banks will definitely still do it, including resources from the issuance to matching funds as subordinated liabilities. However, this fact notwithstanding, the risk arising from the issuance of bonds by cooperative banks remains unaffected and comes down to the dangers related to: issuer bankruptcy, changes in bonds market price, small bank characteristics, holding up credit activity, ineffective market valuation of selected series of bonds, changes in interest rates, lack of liquidity, destabilisation of cooperative banking system, decrease in a bank's creditworthiness - risk of bankruptcy, lack of appropriate bond coverage, long redemption period, losing resources obtained by selling cooperative bonds, macroeconomic factors, interest rate risk, bonds duration, debt of the issuer and profitability against debt of the issuer.

Analysis of the security level of cooperative bonds in the following areas: D (average duration), $\mathrm{V}$ (convexity) and risk indicator (ID) shows that investments in 
the bonds under analysis are relatively secure. The accepted research hypothesis was therefore verified positively for these parameters. A high level of risk has been identified for the PID indicator. Here, the research hypothesis was verified negatively. The calculated level of this ratio indicates that the company, while dedicating the entire EBITDA result to debt repayment, cannot repay its debt in a given period. This issue should be further study.

Cooperative bonds are thought to be more risky than communal or treasury bonds, however more favourable interests compensate for this risk. Debt securities issued by cooperative banks can surely be an interesting completion of investment portfolio, on the condition that the risk of their occurrence had earlier been mitigated.

\section{References}

Alińska A., 2002, Bankowość spótdzielcza w krajach Unii Europejskiej, Twigger, Warszawa. BFG, 2017, Sytuacja w sektorze bankowym - informacja miesięczna, BFG, Departament Analiz i Wczesnego Ostrzegania, Warszawa.

Buszko M., Kołowska B., 2012, Obligacje banków spótdzielczych w Polsce na przykładzie instrumentów notowanych na rynku Catalyst, [in:] Finanse w niestabilnym otoczeniu - dylematy i wyzwania, Zeszyty Naukowe Uniwersytetu Ekonomicznego w Katowicach, Katowice.

Catalyst, 2018, www.gpwcatalyst.pl [access: 15.01.2019].

Cioch H., 2011, Prawo spótdzielcze, Wolters Kluwer, Warszawa.

Desrochers M., Fischer K., 2005, The power of networks: Integration and financial cooperative performance, Annals of Public and Cooperative Economics, no. 3.

Elton E.J., Gruber M.J., Brown S.J., Goetzmann W.N., 2003, Modern portfolio theory and investment analysis, Wiley, New York.

Fisher L., Weil R.L., 1971, Coping with the risk of market rate fluctuations: Returns to bondholders from naive and optimal strategies, Journal of Business, no. 4.

Fonteyne W., 2007, Cooperative banks in Europe - Policy Issues, IMF Working paper, WP/07/159, International Monetary Fund, Washington.

Galbarczyk T.A., 2012, Emisja papierów wartościowych jako forma powiększania funduszy własnych banków spótdzielczych, [in:] Finanse w niestabilnym otoczeniu - dylematy i wyzwania, Zeszyty Naukowe Uniwersytetu Ekonomicznego w Katowicach, Katowice.

Gontarek I., Dorosz A., 2011, Obligacje spótdzielcze na Catalyst, Giełda Papierów Wartościowych w Warszawie, Warszawa.

Guinnane T.W., 1997, Regional organizations in German cooperative banking system in the late 19th century, Research in Economics, no. 3.

GUS, 2018, Wyniki finansowe banków w 2017 roku, December, GUS, Warszawa.

Jakubowski A., 2012, Czynnikowy model zarządzania portfelem obligacji, Zeszyty Naukowe Wydziału Informatycznych Technik Zarządzania Wyższej Szkoły Informatyki Stosowanej i Zarządzania: Współczesne problemy zarządzania no.1, Warszawa.

Nastarowicz E., 2017, Bankowość spółdzielcza - wyróżniki, misja, wartości, Centrum Prawa Bankowego i Informacji, Warszawa.

NBP, 2015, Raport o stabilności systemu finansowego, December, Departament Stabilności Finansowej NBP, Warszawa. 
NBP, 2016, Raport o stabilności systemu finansowego, December, Departament Stabilności Finansowej NBP, Warszawa.

NBP, 2017, Raport o stabilności systemu finansowego, December, Departament Stabilności Finansowej NBP, Warszawa.

NBP, 2018, Raport o stabilności systemu finansowego, December, Departament Stabilności Finansowej NBP, Warszawa.

Orzeszko T., 1998, Banki spółdzielcze w Polsce. Ekonomiczne i finansowe warunki rozwoju, WSB, Poznań.

Osiecki M., 2016, Oferta obligacji banków spótdzielczych na rynku Catalyst, www.StockWatch gpwcatalyst.pl [access: 15.01.2019]

Pawlonka T., 2012, Emisja obligacji przez banki spótdzielcze - doświadczenia z obecności na rynku Catalyst, [in:] Finanse w niestabilnym otoczeniu - dylematy i wyzwania, Zeszyty Naukowe Uniwersytetu Ekonomicznego w Katowicach, Katowice.

Rosa A., 2010, Efektywność spółdzielczego sektora bankowego w Polsce w latach 1999-2009, [in:] Bankowość a kryzys na rynkach finansowych, Zeszyty Naukowe no. 140, Wydawnictwo Uniwersytetu Ekonomicznego w Poznaniu, Poznań.

Rosa A., 2012, Aktywność banków spótdzielczych w Polsce i na tle wybranych europejskich spótdzielczych grup bankowych, [in:] Finanse w niestabilnym otoczeniu - dylematy $i$ wyzwania, Zeszyty Naukowe Uniwersytetu Ekonomicznego w Katowicach, Katowice.

Stanisz A., 1998, Przystępny kurs statystyki, Statsoft Polska, Kraków.

Szambelańczyk J., 2006, Banki spótdzielcze w Polsce w procesach zmian systemowych, Wydawnictwo Akademii Ekonomicznej w Poznaniu, Poznań.

Ustawa z dnia 1 lipca 2009 r. o zmianie ustawy o funkcjonowaniu banków spółdzielczych, ich zrzeszaniu się i bankach zrzeszających, Dz.U. Nr 127, poz. 1050, art. 1 pkt 1-2.

Ustawa z dnia 29 sierpnia 1997 r. - Prawo bankowe, Dz.U. 2002, Nr 72, poz. 665 z późn. zm., art. 2.

Ustawa z dnia 7 grudnia 2000 r. o funkcjonowaniu banków spółdzielczych, ich zrzeszaniu się i bankach zrzeszających, Dz.U. Nr 119, poz. 1252 z późn. zm., art. 6 ust. 1-3i art. 7-8.

Wyman O., 2008, Cooperative bank: Customer champion, https://v3.globalcube.net/clients/ eacb/content/medias/publications/external_studies/CBank_Costumer_Champion.pdf [access: 25.11.2019].

Zalewska Z., 2009, Banki spótdzielcze w okresie turbulencji na rynkach finansowych, Głos Banków Spółdzielczych, no. 2.

J. Pera (-) peraj@uek.krakow.pl

Uniwersytet Ekonomiczny w Krakowie, ul. Rakowicka 27, 31-510 Kraków, Polska 